\section{耍 Heighten Science \\ P U B L I C I T I O N S Corporation ISSN 2639-6769}

\title{
The master regulator gene PRDM2 controls C2C12 myoblasts proliferation and Differentiation switch and PRDM4 and PRDM10 expression
}

\author{
Di Zazzo Erika1", Bartollino Silvia ${ }^{1 * \#}$ and Moncharmont Bruno ${ }^{1}$ \\ 'Department of Medicine and Health Sciences "V. Tiberio", University of Molise, Italy \\ "These authors contributed equally to this work
}

*Address for Correspondence: Silvia Bartollino, Department of Medicine and Health Sciences, " $V$. Tiberio", University of Molise Via F. De Sanctis, 86100 Campobasso, Italy, Tel.: +39 0874404886 , E-mail: silvia.bartollino@unimol.it

Submitted: 11 August 2017

Approved: 20 September 2017

Published: 25 September 2017

Copyright: @2017 Di Zazzo E, et al. This is an open access article distributed under the Creative Commons Attribution License, which permits unrestricted use, distribution, and reproduction in any medium, provided the original work is properly cited.

Keywords: PRDM; RIZ; Cell cycle; Proliferation; Differentiation

\section{Abstract}

The Positive Regulatory Domain (PRDM) protein family gene is involved in a spectrum variety of biological processes, including proliferation, differentiation and apoptosis: its member seem to be transcriptional regulators highly cell type and tissue peculiar, towards histones modifications or recruitment of specific interaction patters to modify the expression of target genes. In this study we analyzed the expression profile of different member of PRDM gene family focusing our attention on the role of PRDM2, PRDM4 and PRDM10 genes in mouse $\mathrm{C} 2 \mathrm{C} 12$ cell line, during the differentiation of myoblasts into myotubes and speculate about the role of the protein Retinoblastoma protein-interacting zinc finger protein 1-RIZ1, coded by PRDM2 gene, as a regulator of the proliferation/differentiation switch.

Results showed a reduction of PRDM2, PRDM4 and PRDM10 expression level during the commitment of the differentiation of myoblasts into myotubes. The RIZ1 silencing stimulated myoblasts differentiation, similar to the effect of serum deprivation on these cells, associated with an increase of Myogenin expression level, which is considered to be involved in the differentiation of myoblasts into multinucleated myotubes. As demonstrated by chromatin immunoprecipitation experiments, RIZ1 is associated with Myogenin promoter in proliferation condition and after $24 \mathrm{~h}$ from differentiation induction, negatively controlling therefore Myogenin expression. Moreover RIZ1 silencing induced a reduction in PRDM4 and PRDM10 expression levels leaving us to speculate that the PRDM genes have a redundant role and they are hierarchically organized.

\section{Introduction}

The myogenesis of mammalian skeletal muscle cells is regulated by myogenic regulatory factors (MRFs), related in a hierarchical relationship [1], which are considered to be members of a superfamily of the highly conserved variant of the basic helix-loop-helix (bHLH) domain [2], that confers their peculiar myogenic potential [3]. The phylogenetic analysis of the sequences of these genes indicates that MRF genes have evolved from a single ancestral MRF gene progenitor, by gene duplication events followed by divergent mutations [4]. The four main basic helix-loop-helix myogenic regulatory factors, which exhibit a pivotal role in skeletal muscle development and which are responsible for coordinating muscle-specific gene expression in the developing embryo [5], are MyoD (Myf-3) [3], which coordinates an open chromatin structure at muscle-specific genes [1]; Myf-5 [6], which is required for the specification and proliferation of myoblasts [7-10], enhances myogenesis by promoting myoblast proliferation [11-13], because it is also the earliest to be expressed during myogenesis process, acting as a transcription factor in muscle progenitor cells (satellite cells) and myocytes [14]; Myogenin (Myf-1) [15], which is involved in the differentiation of myoblasts into multinucleated myotubes [16] and MRF4 [17], which is implicated 
in the latest phase of differentiation that includes myofiber maintenance [18]. The Myogenic regulatory factor (MRF) genes are expressed with a peculiar pattern $[19,20]$ and they can auto- and cross-regulate the expression of each other and interact with the myocyte enhancer factor-2 (MEF2) family of transcription factors, to activate the transcription of muscle-specific genes [21]: currently, these MEF2 transcription factors are considered to drive the development of muscle, cardiac, skeletal, vascular, neural and blood cells, because of their pivotal effects on cell differentiation, proliferation, apoptosis, migration, shape and metabolism [22].

The activity of MRF proteins require heterodimerization with a member of the ubiquitously expressed E-protein family of bHLH proteins. This event leads the binding to the regulatory regions of muscle-specific genes on the E-box consensus sequence (CANNTG) [5]. Currently, only a small fraction of 14 million potential sites are available for MRF binding [23,24]. MyoD, the master regulator of the skeletal muscle gene expression program, activates genes which display the consensus E-box sequence VCASCTG (where $\mathrm{V}$ is $\mathrm{A}, \mathrm{C}$ or $\mathrm{G}$ while $\mathrm{S}$ is $\mathrm{C}$ or $\mathrm{G}$ ) within their promoter/enhancer regions [23,25-27] and it leads a gene expression program by heterodimerizations with E-proteins and giving rise to multinucleated myotubes [28]. The binding of MyoD on the E-box sequence (CANNTG) and the recruitment of factors, which are involved in remodelling the chromatin, are considered the crucial event for transcription $[29,30]$ because MyoD activates $\mathrm{pRb}$ and $\mathrm{p} 21$ gene expression $[31,32]$ to shoot down the cell cycle machinery [29]. The skeletal muscle differentiation is a strongly coupled event to the cell cycle exit [33] by an upregulation of cyclin-dependent kinase inhibitors (CDKIs), which inhibit cyclin-CDK complexes driving a downregulation of the activity of cyclin D1,E,A, and B-CDK complexes [34] and by an induction of the permanent cell cycle exit. This is a pivotal step because of the overexpression of cyclin/CDKs has been reported to inhibit the activity of MyoD by different mechanisms [29]. In particular, p21cip1/ waf1, and p57/kip2, encoded respectively by Cdkn1a and Cdkn1c genes, control differentiation of skeletal muscle and their loss affects fiber formation: they have a key role both for cell cycle exit, both in triggering a muscle-specific transcriptional program [35]. The PRDM (Positive Regulatory Domain) gene family which consists of 17 orthologs in primates and 16 orthologs in rodents, birds and amphibians [36], encodes transcription factors with a PR domain and a variable number of zinc finger motifs [37], with the exception of PRDM11 [36,38]. The PR domain displays a 20$30 \%$ amino acid homology sequence to the catalytic SET (Suvar3-9, Enhancer-of-zeste, Trithorax) domain with hystone lysine methyltransferase (HMTs) activity [39]. In contrast to the SET domain proteins, currently only three PRDM proteins have been demonstrated to possess intrinsic HMTase activity [40] and a number of PRDMs have not endowed with catalytic activity towards histones/nucleosomes [41-44]. In particular the HMT's activity has been found only in the PR domains of PRDM2/RIZ1, Prdm8 and Prdm9 [45-47]. In fact, the PR domain has diverged significantly from the SET domain [48-51] and most PR domains lack the $\mathrm{H} / \mathrm{RxxNHxC}$ motif required for methyltransferase activity [52,53]. Generally, the PR domain is localized at the $\mathrm{N}$-terminus of the protein, whereas the SET domain is often localized to the C-terminus [39]. A common characteristic of PRDM genes is the expression of molecular variants by alternative splicing or by alternative use of promoters. The PRDM1, PRDM2 and PRDM3, which is also called MECOM (MDS1-EVI1 complex locus) genes are expressed as two alternative forms, by intergenic splicing, which produce the PR plus and PR minus forms of these genes [54-57]. PR plus and PR minus forms are expressed at equimolar concentration and their ratio is maintained in a fine equilibrium [58]: an imbalance in the amounts of the two products, through either disruption or underexpression of the PR plus form or overexpression of the PR minus form commonly occurs in human cancers through genetic and epigenetic mechanisms [59-66]. PRDM2 gene gives two alternative products: RIZ1, the PR plus form, implicated in tumor suppressor function, and RIZ2, the PR minus form. This PR domain (PRDI-BF1 and RIZ homologous) [67] which is endowed with histone H3 K9 methyltransferase activity, is targeted by inactivating mutations in human cancers [68]. 
PRDM proteins mediate transcriptional activation or repression depending on the nature of their intrinsic HMT activity: PRDM proteins appear to function by modulating gene expression states either directly (via intrinsic HMTase activity), or indirectly (via recruitment of various cofactors), controlling critical aspects of cell integrity, spanning from cell differentiation to cell growth and apoptosis [58]. These genes also play a role in human cancer, where they mainly act as tumor suppressors: for example, PRDM1 is a tumor suppressor of diffuse large B cell lymphoma (DLBCL); PRDM3 and PRDM16 show different isoforms with separate functions in leukemia [44,69]. PRDM16 (PRD1BF1-RIZ1 homologous domain containing 16) controls a bidirectional cell fate switch between skeletal myoblasts and brown fat cells [70], the targeting of 3'UTR of Prdm16 is involved in the choise between myogenic and brown adipose determination of the adult skeletal muscle stem cells (satellite cells) [71], PRDM5 acts with a potential tumor suppressor role for gastrointestinal carcinogenesis [72-74].

The RIZ proteins regulate cell proliferation in a yin-yang manner $[57,58,75]$ : gene silencing of the RIZ1 form, by genetic or epigenetic mechanisms, has been described in a variety of human tumors [14], whereas the RIZ2 form, lacking of PR domain, is always present or overexpressed [76]: this finding suggests a positive selection for RIZ2 in cancer progression. Further evidence indicates that forced expression of RIZ1 in tumor cell cultures induces growth arrest and apoptosis, possessing an anticancer activity in the PR domain [77], and the silencing of RIZ1 expression can stimulate breast cancer cell proliferation [78]. In addition, forced expression of the Zn-finger domain present in both RIZ forms increases the growth rate of breast cancer cells [79]. Based on these findings, RIZ1 could be considered as a crucial tumor suppressor gene candidate and the Zn-finger domain could be responsible for the putative oncogenic activity of the RIZ2 gene product. Such an effect might be more relevant in estrogen target tissues, where RIZ gene products are reported to directly interact with the estrogen receptor in a hormone-dependent manner through a LXXLL motif [80,81], promoting optimal estrogen response; conversely, in osteosarcoma cancer cell line (SAOS2), RIZ1 is expressed at high level in proliferating cell compared to serum-free culture conditions [82]. Murine models studies demonstrated that PRDM1 regulates commitment, as well PRDM14, PRDM9 is involved in meiosis [83], PRDM16 is involved in the switch controlling of myoblast differentiation to brown adipocytes [70,84]; PRDM3 and PRDM16 are also required for the maintenance of brown adipocyte identity [85], but currently the PRDM2 role in the development and in myoblast differentiation is still unclear. The purpose of this study therefore was to investigate the expression profile and the role of PRDM genes in the molecular mechanism responsible of the proliferation-differentiation switch, paying particular focus on the PRDM2 gene expression in skeletal muscle C2C12 cell line, an established cell model for skeletal muscle differentiation studies [86,87], that has been successfully used to study differentiation and proliferation-differentiation switch [88].

\section{Materials and Methods}

\section{Cell culture and transfection}

C2C12 cells (kindly provided by Professor Fabio Naro from University "La Sapienza"Rome) were maintained in DMEM (Invitrogen, Carlsbad, CA, USA) supplemented with 10\% fetal bovine serum, FBS (Invitrogen), referred as GM, i.e. growth medium, in humidified $95 \%$ air and $5 \% \mathrm{CO}_{2}$. As the cells reached confluence, the medium was replaced with DMEM supplemented with $10 \mu \mathrm{g} / \mathrm{ml}$ insulin (Invitrogen). And $5 \mu \mathrm{g} /$ $\mathrm{ml}$ transferrin (Invitrogen) referred as DM, i.e. differentiation medium, to induce differentiation of myoblasts into myotubes. Cell transfection with plasmid DNA was performed using Lipofectamine ${ }^{\circledR} 2000$ Reagent (GIBCO BRL, Life Technologies, Rockville, MD, USA) in OptiMem I Reduced Serum Medium (Invitrogen) for 6 hours, according to the manufacturer's instructions. Transfection medium was then removed, 
and cells were grown in DMEM supplemented with 5\% FBS or DM, as indicated in the legend to figures, for additional 24-48-72 hours. Reverse transcriptase-polymerase chain reaction (RT-PCR)-Total RNA $(1 \mu \mathrm{g})$ was extracted from C2C12 cells using Trizol reagent (Invitrogen), according to the manufacturer's instructions. Gel electrophoresis in denaturing conditions was performed to evaluate the integrity of extracted RNA; the quality of RNA extracted was evaluated by the measure of 260/280 nm and $260 / 230 \mathrm{~nm}$ absorbance ratios (the threshold acceptance was 1.9 for absorbance ratio 260/280 $\mathrm{nm}$ and 2.2 for absorbance ratio 260/230). To remove contaminant DNA, RNA samples were treated with $40 \mathrm{U}$ of RNase-free DNase-I (Boehringer Mannheim, Indianapolis, IN, USA) for 45 minutes at $37^{\circ} \mathrm{C}$. The absence of contaminant genomic/ plasmid DNA was checked by PCR of not reverse transcribed RNA samples. Total RNA was reverse transcribed using cDNA Synthesis Kit Transcriptor High Fidelity (Roche, Basilea, Switzerland). The cDNAs amplifications were performed by RT-PCR with specific primers set for glyceraldehyde-3-phosphate dehydrogenase (GAPDH)s, for MRF and for the detection of the PRDM plus transcript (PRDM PR as reported in table 1) and also for all PRDM transcripts (PRDM TOT as reported in table 1) using JF buffer (30mM Tris base, $8 \mathrm{mM}$ HEPES base, $20 \mathrm{mM} \mathrm{K}$ glutamate, $60 \mathrm{mM} \mathrm{NH}_{4}$ acetate, $2 \mathrm{mM}$ DTT, $8 \%$ glycerol, $1.5 \mathrm{mM} \mathrm{MgCl}, 0.2 \mathrm{mM}$ dNTPs) [79]. The reaction was performed using a thermal cycler (Eppendorf, Milan, Italy). Analysis of amplified products was done by electrophoresis on 2\% agarose gel. The gel images were acquired by the Gel DOC XR System platform (Bio-Rad laboratories, Hercules, CA).

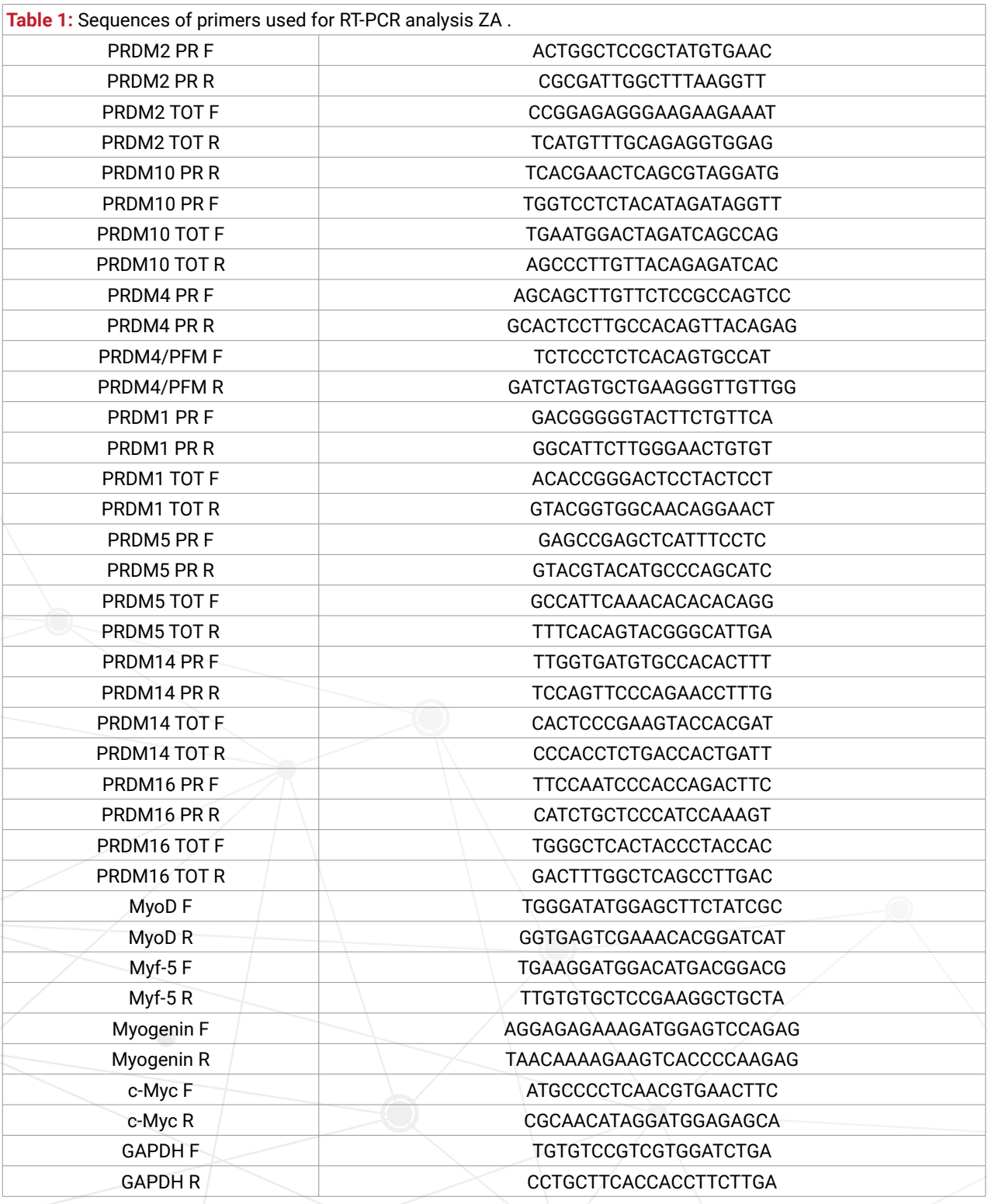


Quantitative Reverse-Transcription PCR (qRT-PCR) Analysis-Aliquots of cDNA were subjected to quantitative analysis by real-time PCR ( $q R T$-PCR) using the SYBR Green PCR Master Mix (Applied Biosystems, Foster City, CA) in a Mastercycler ep Realplex (Eppendorf), as previously described [89]. The amplification was performed using the same primer sets of semi-quantitative RT-PCR. GAPDH was used as housekeeping gene for normalization. The dissociation curves showed a single peak and the agarose gel analysis of PCR amplicons showed a single DNA band of the expected molecular size. The relative quantification (RQ) was performed using the $\Delta-\Delta \mathrm{Ct}$ method [90]. Data were presented as RQ (Relative Quantification) by comparing the threshold cycle of PCR products to the threshold cycle of standard cDNA. The linearity and the efficiency of the PCR reaction were analyzed by serial cDNA dilutions. Each amplification was done in triplicate and the reaction specificity was assessed by melting curves analysis. PRDM2 PR silencing by RNA interference -The gene silencing of PRDM2 PR gene product was achieved using the BLOCK-iT ${ }^{\mathrm{TM}}$ Pol II miR RNAi with emGFP expression vector (Invitrogen), according to the manufacturer's instructions. The oligonucleotides, Hmi418948 and Hmi418951, which target PRDM2 PR gene product (Invitrogen Co.), were cloned into the vector ( $\mathrm{pcDNA}^{\mathrm{TM}}$ 6.2-GW/EmGFP-miR). C2C12 cells were transfected with recombinant vector or with kit control vector ( $\beta$-galactosidase, CTRL). Protein assay -The protein concentration was measured with BIO-RAD Protein Assay (Bio-Rad Laboratories, Hercules, CA) according to the manufacturer's instructions.

Western blot analysis- C2C12 cells were washed with PBS and lysed in RIPA buffer 1X [50 mM Tris $\mathrm{HCl} \mathrm{pH} \mathrm{7.5,} 150 \mathrm{mM} \mathrm{NaCl}, 0.25 \%$ sodium deoxycholate, 1\% NP-40 supplemented with protease inhibitor cocktail (Roche, Basilea, Svizzera). The clarified lysates were processed for Sodium Dodecyl Sulphate - PolyAcrylamide Gel Electrophoresis, SDS- PAGE (10\% polyacrylamide gel) according to Laemmli procedure [91]; subsequently the proteins were transferred to PVDF membrane (Santa Cruz Biotechnology, Inc., Santa Cruz, CA) using transfer buffer. Blots were blocked with 20 mM Tris pH 7.8, $100 \mathrm{mM} \mathrm{NaCl}, 0.1 \%$ Nonidet P40/Tween 20(1:1), 5\% non-fat milk and incubated with primary antibodies diluted in the same buffer $\left(0.1 \mathrm{ml} / \mathrm{cm}^{2}\right)$. The following antibodies were used at the indicated concentrations: mouse monoclonal antiMyoD: sc-32758 (Santa Cruz Biotechnology) at the following concentration $0.2 \mu \mathrm{g} / \mathrm{ml}$; mouse monoclonal anti- Myc: sc-40 (Santa Cruz Biotechnology, Inc., Santa Cruz, CA) at the following dilution 1:500; mouse monoclonal anti-Myogenin: sc12732 (Santa Cruz Biotechnology, Inc.,Santa Cruz,CA) at the following dilution 1:500; rabbit polyclonal antibodies to RIZ1, RIZ 9710 (Abcam Ltd., Cambridge, UK) at the following dilution 1:1000, rabbit polyclonal antibodies against PRDM4 and PRDM10 (EPIGENTEK) at the following dilution 1:1000. Thereafter the same filter was stripped and reprobed with mouse monoclonal antibody against Histone H1 (Santa Cruz Biotechnology, Inc., Santa Cruz, CA) at the following dilution 1:1000. Peroxidase-conjugated anti-rabbit IgG or anti-mouse IgG secondary antibodies were used at 1:5000 dilution. Peroxidase activity was detected using an Amersham ECL ${ }^{\mathrm{TM}}$ Advance Western Blotting Detection Kit (GE Healthcare, Little Chalfold, UK), according to the manufacturer's instructions. Membranes were exposed with Amersham Hyperfilm ECL film (GE Healthcare, Little Chalfold, UK) and images were acquired with the Gel DOC XR Platform (Bio-Rad Laboratories, Hercules, CA).

Cell growth analysis- Cell proliferation was evaluated by cell counting, by MTT (3-(4,5dimethylthiazol-2-yl)-2,5-diphenyltetrazolium bromide) assay (Sigma-Aldrich, Co. St. Louis, MO, USA) and by FACS (Fluorescence Adsorbed Cell Sorting, Becton Dickinson, New Jersey, USA) analysis as previously indicated [58].

\section{Immunofluorescence analysis}

Myoblasts were plated on poly-L-lysine (3x)-coated coverslip and cultured in DM for $72 \mathrm{~h}$. Subsequently DM was discarded and cells washed three times with PBS and 
incubated at room temperature with freshly-made paraformaldehyde $(4 \% \mathrm{w} / \mathrm{v})$ for $10 \mathrm{~min}$. The cells were washed with glycine $0.1 \%$ for $5 \mathrm{~min}$, followed by three washing in PBS, subsequently incubated for 2 hours with the following primary antibodies: (a) mouse monoclonal anti-MyHC (Sigma-Aldrich, Co. St.Louis, MO,USA) at the following dilution 1:500; (b) RIZ 9710 (Abcam Ltd, Cambridge, UK) at the following dilution 1:100. The primary antibodies were diluted in PBS containing $10 \%$ (v/v) fetal bovine serum (FBS) and $0.1 \%$ Triton X-100. Cells were then washed in PBS and incubated at room temperature for $1 \mathrm{~h}$ with fluorescent secondary antibodies (Jackson Laboratories, USA): (a) anti-mouse or anti-rabbit IgG conjugated to Texas red were diluted 1:100 in PBS containing $10 \%(\mathrm{v} / \mathrm{v})$ fetal bovine serum (FBS) and $0.1 \%$ Triton X-100. Subsequently, coverslips were placed onto untreated glass slides and allowed to air dry. Coverslips were analyzed using a Zeiss LSM 510 Meta argon/krypton laser scanning confocal microscope. Each image was acquired 4 times and the signal averaged to improve the signal to noise ratio. Computer-assisted quantitative evaluation of channel distribution in cell compartment was done using the Image-J software.

\section{Chromatin immunoprecipitation (ChIP)}

C2C12 cells (approximately $5 \times 10^{6}$ cells/plate) were cultured in GM or in DM for 24,48 and 72 hours. One-tenth aliquots were immunoprecipitated using the following antibodies: $1 \mu \mathrm{g}$ of purified IgG control antibody (Sigma-Aldrich), $1 \mathrm{mg}$ of rabbit polyclonal anti-RIZ1 (Abcam Ltd, Cambridge, UK) or $1 \mu \mathrm{g}$ of mouse monoclonal antiMyoD (Santa Cruz Biotechnology Inc., Santa Cruz, CA). Secondary immunoprecipitation was performed with Sepharose coupled to protein A (Sigma-Aldrich, Co. St. Louis, MO, USA). One-twenty-fifth of the DNA extracted from each immunoprecipitation was amplified using primers complementary to the Myogenin promoter region E2_E1 Forward-GAATCACATGTAATCCACTGGA E2_E1 Reverse-ACGCCAACTGCTGGGTGCCA). Amplifications were performed for an empirically determined number of PCR cycles producing a linear correlation between amplified band signals and template dilutions. AmpliTaq polymerase in AB1 buffer $(30 \mathrm{mM}$ Tris base, $10 \mathrm{mM}$ HEPES base, $25 \mathrm{mM} \mathrm{KCl}$, $20 \mathrm{mM} \mathrm{K}$ glutamate, $20 \mathrm{mM} \mathrm{NH} 4$ acetate, $1.25 \mathrm{mM}$ DTT, $5 \%$ glycerol, $1.25 \mathrm{mM} \mathrm{MgCl}$, $0.2 \mathrm{mM}$ dNTP) (Applied Biosystems, Foster City, CA) was used for all PCR analyses. Amplification products were analyzed by $2 \%$ agarose gel electrophoresis and bands were visualized with the Gel DOC XR System (Bio-Rad laboratories, Hercules, CA); densitometric analysis was performed using Total Lab 1D software. Statistical analysis -Statistical significance was determined with a paired t-test with Graphpad prism 5.0 software (La Jolla, CA, USA).

\section{Results}

Analysis of the expression levels of MRF genes and PRDM genes in myoblasts and myotubes

To induce differentiation of myoblasts into myotubes, confluent C2C12 cells were incubated in low mitogenic media (DM) and after 72 hours, differentiation is complete as observed by morphological changes. To verify the fidelity of the model used, an immunofluorescence analysis (Figure $1 \mathrm{~S}$ a) of $\mathrm{C} 2 \mathrm{C} 12$ cells differentiated in the same experiment was performed. The results revealed that after $72 \mathrm{~h}$ in DM medium cells formed myotubes expressing the myosin heavy chain (MyHC), a marker of myoblasts differentiation (Figure 1S b-c) [92]. The expression level of PRDM genes (PRDM1, 2, 4, 5, 10, 14 and 16) and MRF genes: Myc and Myogenin was evaluated by qRT-PCR analysis. The amplification of PR plus product was performed with a set of primer amplifying a transcript region encoding for the PR domain (PRDM PR F/R) and another primer set was used for amplification of a region common to both PR plus and PR minus forms (PRDMtot F/R). As expected, the low mitogenic environment increased the expression level of differentiation markers Myogenin and reduced the proliferation markers c-Myc (Figure 1). In our experimental conditions, myotubes showed no significant variation 
in the PRDM1, PRDM5, PRDM14 and PRDM16 expression level than myoblasts. On the other hand, PRDM2, PRDM4 and PRDM10 expression levels falls down into myotubes than myoblasts. So we decided to further investigate the variation in the expression level of PRDM genes that showed a significantly difference in the expression level between myoblasts and myotubes.

\section{Analysis of the expression levels of MRF genes and PRDM genes during differentiation of myoblasts in myotubes}

To induce differentiation of myoblasts into myocytes, confluent $\mathrm{C} 2 \mathrm{C} 12$ cells were incubated in low mitogenic media (DM) and at different time $(0,24,48,72$ hours) was evaluated by qRT-PCR the expression level of MRF genes: $M y c, M y f 5, M y o D$ and Myogenin. As expected, the low mitogenic environment increased quickly the expression
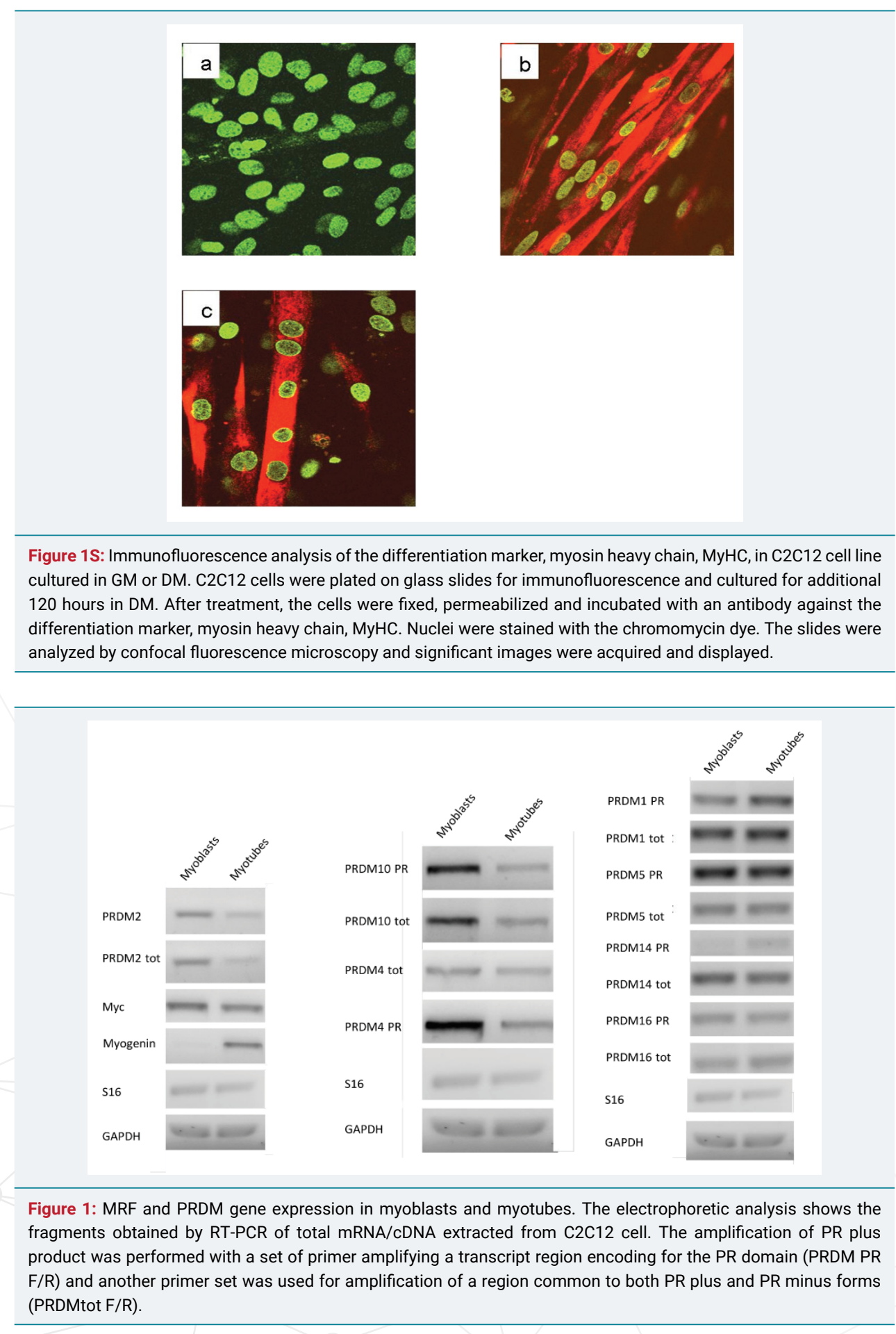
of differentiation markers MyoD and Myogenin and reduced the proliferation markers Myc and Myf5 expression level (Figure 2). It has been extensively demonstrated by Cheedipudi et al. [87], that PRDM2 gene expression levels is lower in myotubes than myocytes but no evidence are available on the variation of other member of PRDM family gene expression level during differentiation induction. In order to determine the precise temporal gap in which occurred PRDM expression level variation, qRTPCR analysis of total C2C12 RNA extracted at different time (24, 48 and 72 hours) from differentiation induction was performed. As shown in figure $3 \mathrm{~A}$ and $\mathrm{B}$, at $24 \mathrm{~h}$ from differentiation induction PRDM2, PRDM4 and PRDM10 genes were expressed at lower level then myoblasts. This reduction was more evident at $72 \mathrm{~h}$ for PRDM2 PR plus product. Interestingly and according to Cheedipudi [87], the maximal expression of Myogenin at $72 \mathrm{~h}$ from differentiation induction corresponds to the reduction of band intensity of PRDM2 PR. The particular behaviour of PRDM2 gene prompted us to investigate the relationship between PRDM2 gene and myoblasts differentiation. Immunofluorescence analysis (Figure 2S) of C2C12 in GM or after culture in DM for 24

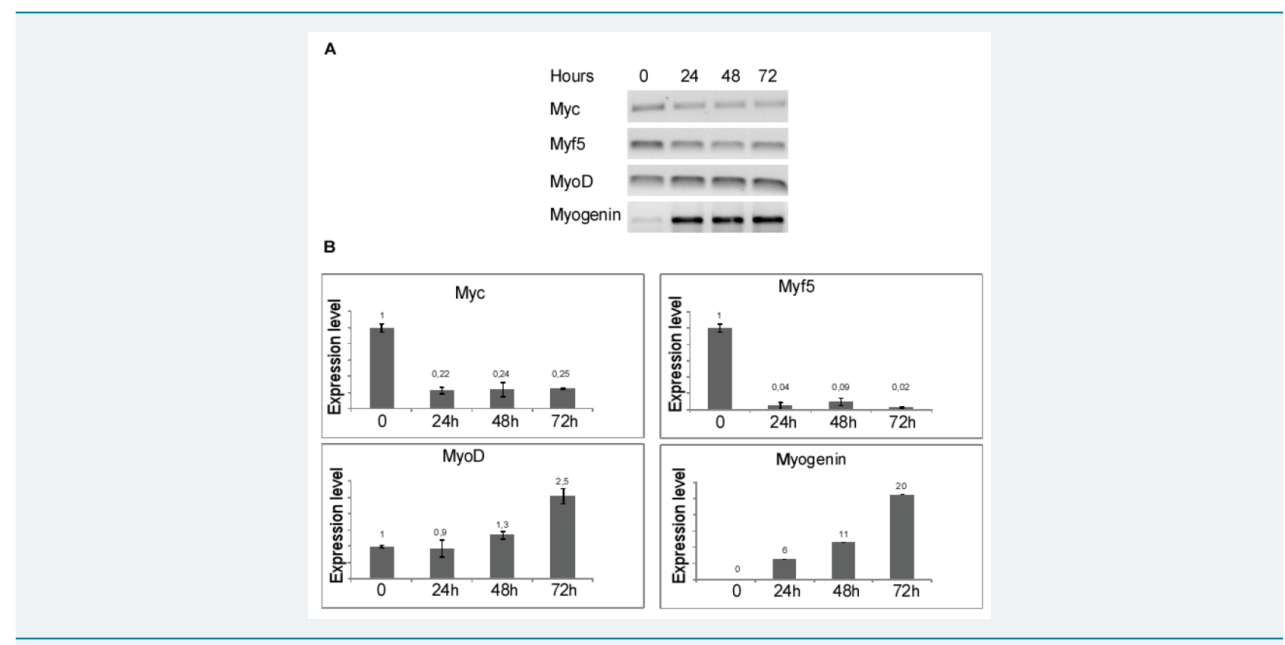

Figure 2: MRF genes expression after induction of differentiation. The transcripts encoded by MRF genes was measured by RT-PCR and qRT-PCR after 24, 48, 72 hours of differentiation induction (see Materials and methods section). The expression level is indicated as fold changes from basal conditions. A) Electrophoretic analysis of the fragments obtained by RTPCR of total mRNA/cDNA extracted from C2C12 cells; B) qRT-PCR of mRNA cDNA extracted from $\mathrm{C} 2 \mathrm{C} 12$ cells. Histograms represent the averages (+/- standard error) from at least three independent experiments, normalized for the expression of the control housekeeping gene GAPDH, reported in figure 2 (\# indicates $p<0.05$ for each gene versus control).

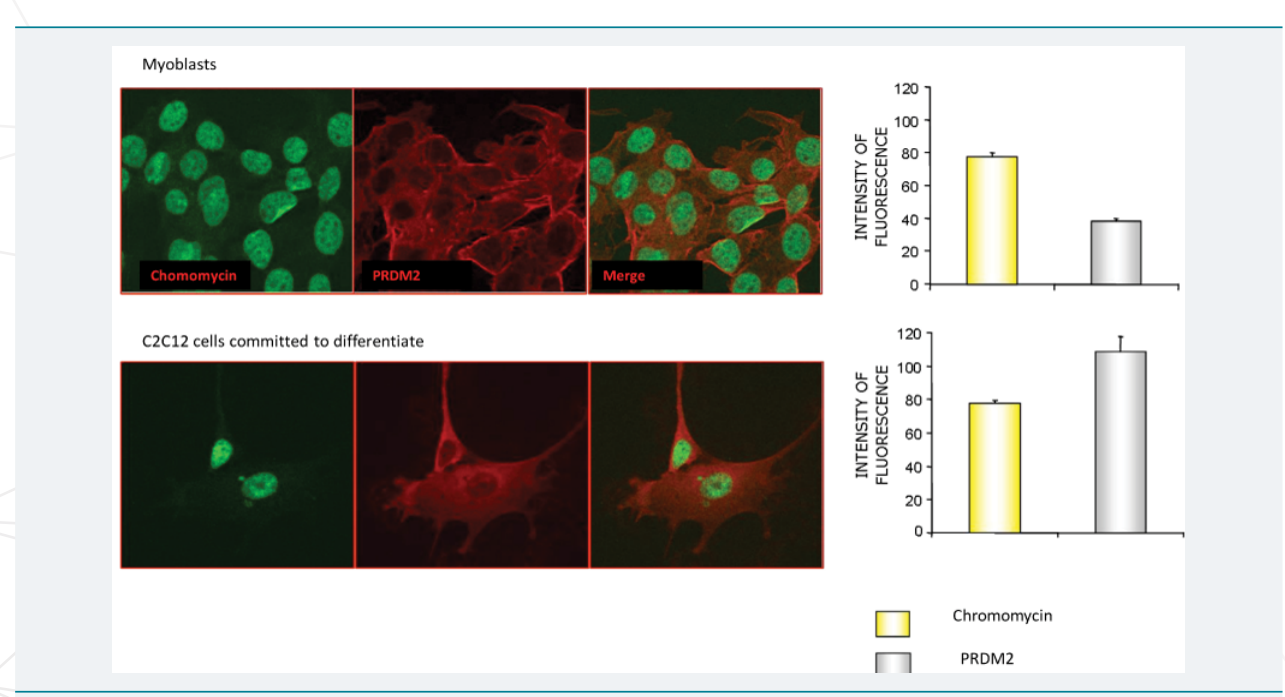

Figure 2S: Immunofluorescence analysis of the RIZ1 protein in the C2C12 cell line cultured in GM or DM. C2C12 cells were plated on glass slides for immunofluorescence and cultured for additional 24 hours in GM or DM. After treatment, the cells were fixed, permeabilized and incubated with an antibody against the RIZ1 protein. Nuclei were stained with the chromomycin dye. The slides were analyzed by confocal fluorescence microscopy and significant images were acquired and displayed. 
$\mathrm{h}$ revealed that RIZ1 in proliferating condition is predominantly localized in the nucleus and translocates into the cytoplasm when $\mathrm{C} 2 \mathrm{C} 12$ cells are committed to differentiate.

\section{Effect of PRDM2 silencing on C2C12 myoblasts differentiation}

As observed by qRT-PCR analysis of PRDM2/RIZ1 (60\%) forced suppression with the plasmid coding the miRNAPRDM2 spanning a sequence coding for the aa 97-103 of RIZ1 protein, induced an increase in expression level of the differentiation markers MyoD and Myogenin that was more evident for the last one (Figure 4). This evidence confirms that RIZ1 protein negatively controls the induction of differentiation mediated by MRF factor. Western blot analysis of whole cell lysates from C2C12 transiently transfected with a control plasmid or with the plasmid coding the miRNAPRDM2,

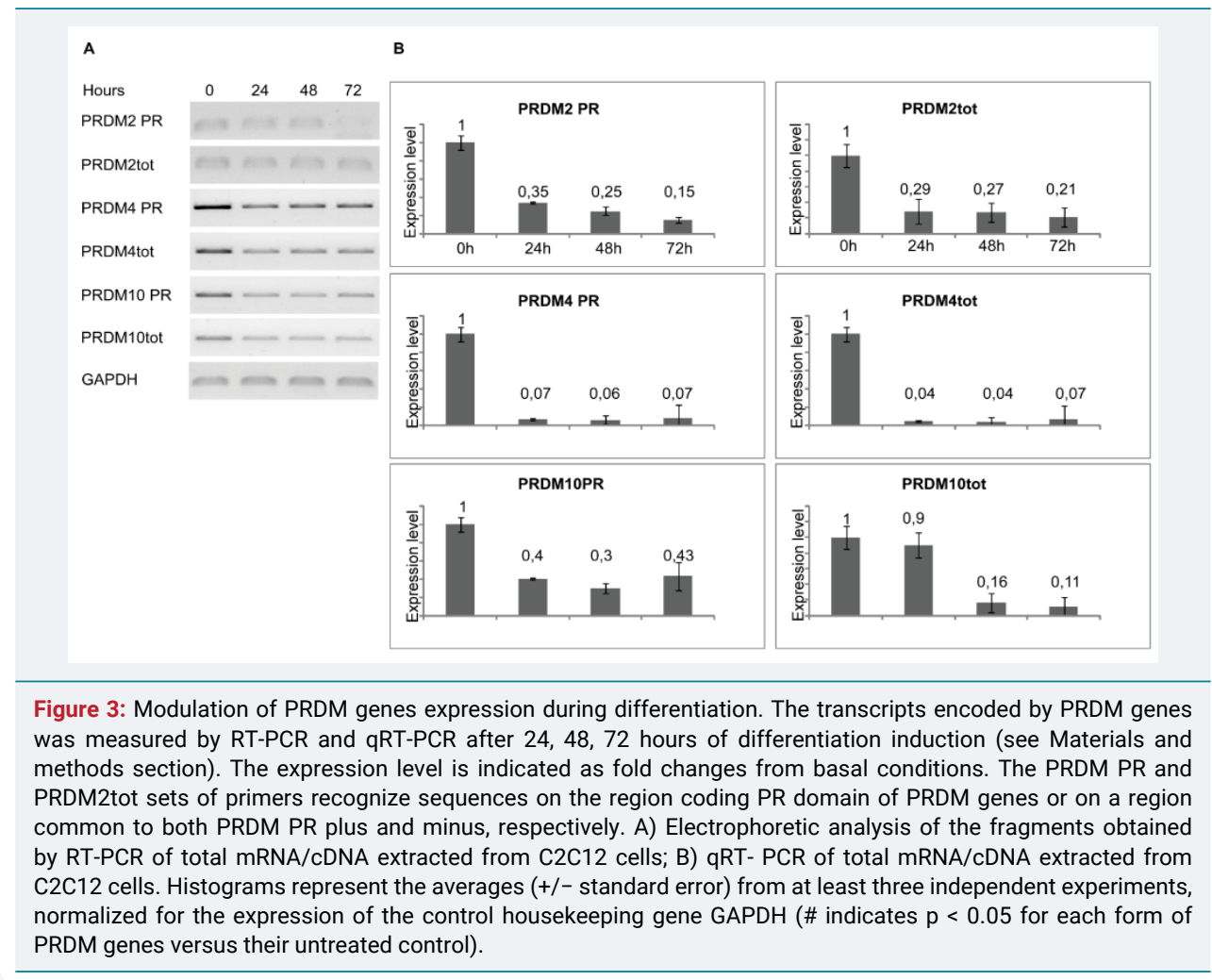

A

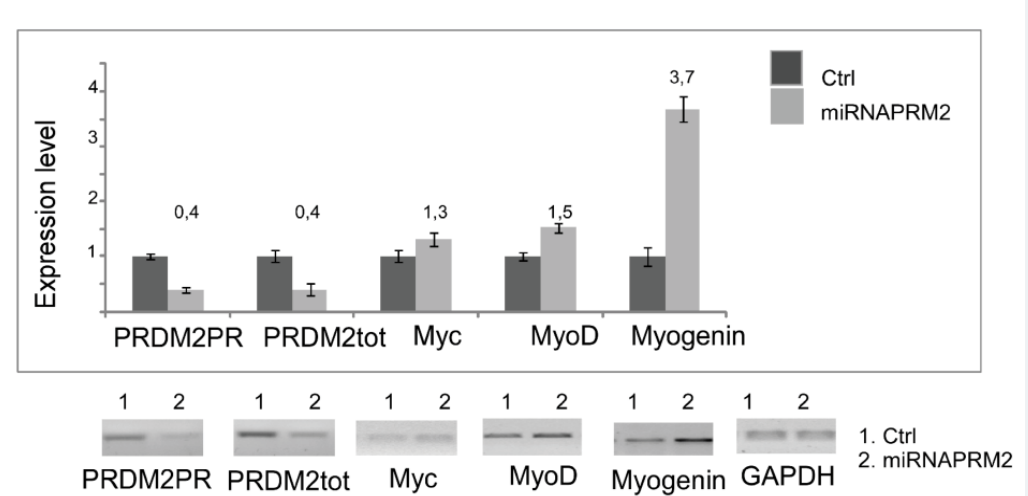

Figure 4: Modulation of MRF genes expression during differentiation. The transcripts encoded by PRDM genes was measured by RT-PCR and qRT-PCR after 24, 48, 72 hours of differentiation induction (see Materials and methods section). The expression level is indicated as fold changes from basal conditions. The PRDM PR and PRDM2tot sets of primers recognize sequences on the region coding PR domain of PRDM genes or on a region common to both PRDM PR plus and minus, respectively. A) Electrophoretic analysis of the fragments obtained by RT-PCR of total mRNA/cDNA extracted from C2C12 cells; B) qRTPCR of total mRNA/cDNA extracted from C2C12 cells. Histograms represent the averages ( $+/-$ standard error) from at least three independent experiments, normalized for the expression of the control housekeeping gene GAPDH (\# indicates $p<0.05$ for each form of PRDM genes versus their untreated control). 
showed a strong reduction in the RIZ1 expression level, revealing the efficacy of the interference (Figure 5). The PRDM2/RIZ1 silencing induced a decrease in the PRDM4 and PRDM10 expression levels. These evidence support the hypothesis that different genes of PRDM family control proliferation/differentiation switch and are probably organized in a hierarchical manner.

\section{Interaction of RIZ with E2/E1 Myogenin promoter region}

ChIP experiments were performed to detect the presence of $M y o D$, a master regulator of the skeletal muscle gene expression program [28], and RIZ on E2/E1 Myogenin promoter region during differentiation induction. Therefore, equivalent amounts of cross-linked chromatin from myoblasts cultured in GM or DM (24, 48 and 72 hours) were immunoprecipitated in parallel with two antibodies that recognize PRDM2/RIZ1 or MyoD. The precipitated DNA then was subjected to PCR amplification with the use of a primers set, spanning two of the E-box sites (E1 and E2) located in the proximal region of Myogenin promoter. Results shown in Fig. 6B, revealed that MyoD was ever associated with Myogenin promoter according to Mal et al., [93]; conversely, as shown in figure 6A, RIZ1 was associated with the E2/E1 Myogenin promoter region

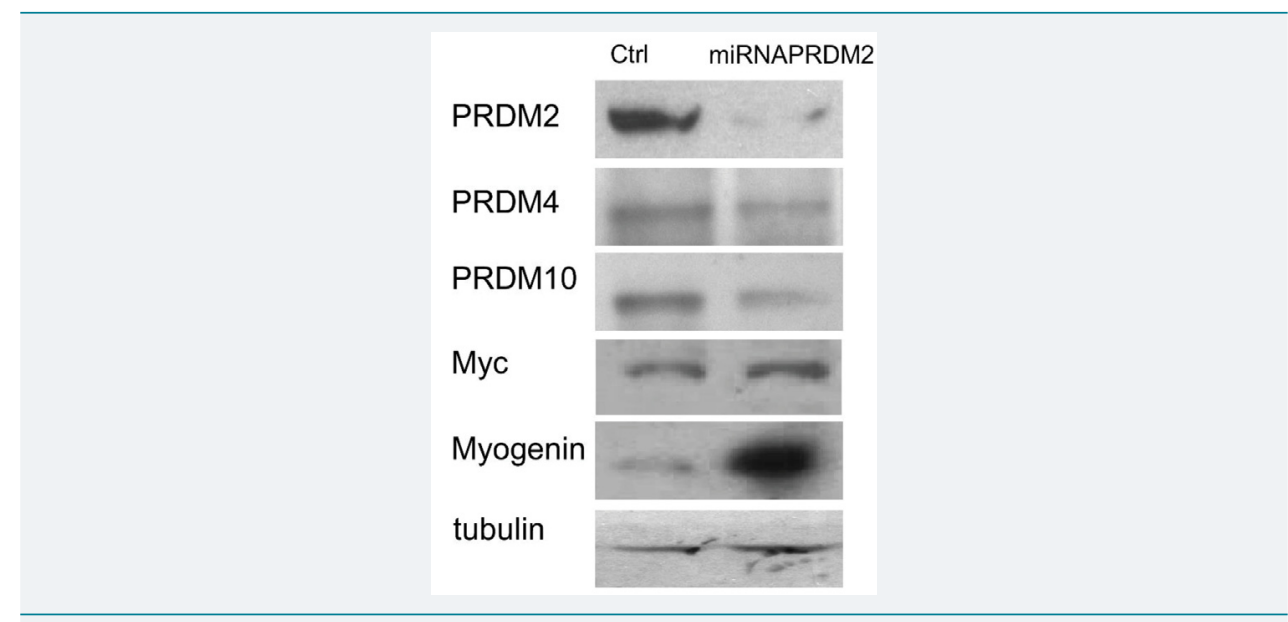

Figure 5: Modulation of PRDM and MRFs proteins expression into PRDM2 silenced C2C12 myoblasts. The expression level of protein encoded by PRDM2, PRDM4 and PRDM10 genes and MRFs was evaluated by SDSPAGE and Western blot analysis of total protein cell extracts from C2C12 myoblasts and PRDM2 silenced C2C12 myoblasts (see Materials and methods section). The blots are representative of three independent experiments.

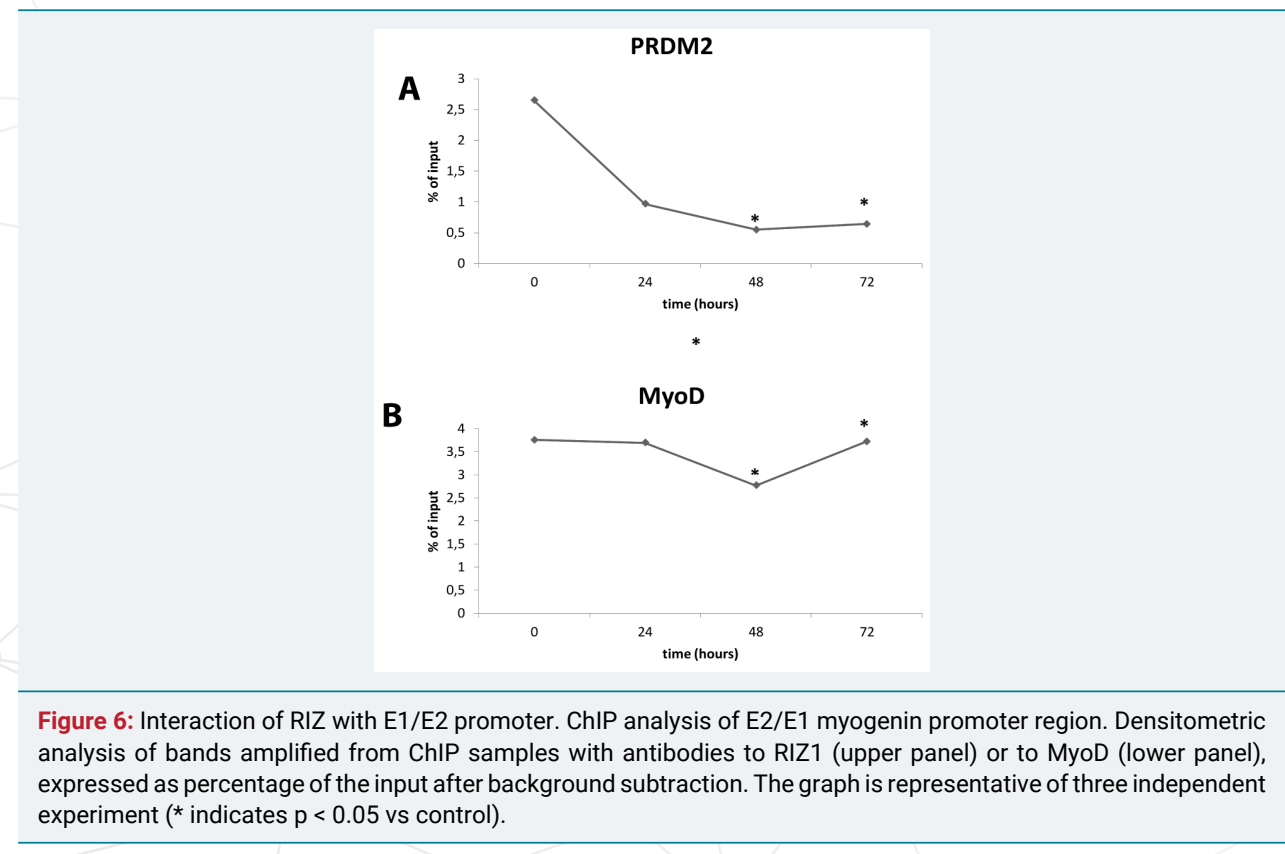


in myoblasts at $24 \mathrm{~h}$ whereas at $48 \mathrm{~h}$ and $72 \mathrm{~h}$ no association of RIZ1 was detected. The specificity of this assay is demonstrated by the observation that the binding of MyoD or RIZ1 was not observed when a normal rabbit IgG was used in the analysis.

\section{RIZ1 silencing induced cell cycle arrest}

In order to investigate the effect of RIZ silencing on proliferation rate, we performed a cell cycle analysis evaluating propidium iodide incorporation by FACS. As shown in figure RIZ1 silencing by miRNA induced a G1 phase delay. Likewise MTT assays of C2C12 cells transfected with the miRNAPRDM2 plasmid significantly reduced the cells number (Figure 7).

\section{Discussion}

PRDM family gene plays a key role in the control of a plethora of cell life processes, like cell cycle progression, homeostasis maintenance of immune system and control of early stage of development. PRDM1 and PRDM14 for example guide the epigenetic reprogramming, necessary to determinate the progenitors of germ cells during embryonic development; $P R D M 9$ also is indispensable for meiotic prophase progression during gametogenesis; PRDM16 controls the cell fate switch between myoblasts and brown adipocytes: recently studies, conducted by Li et colleagues, demonstrated that C2C12 myoblasts, stably transfected with PRDM16, showed a repression of myogenic genes and an upregulation of adipogenic genes at proliferation and differentiation genes, probably due to CpG methylation of MyoD [84]. To this behaviour, the study of molecular basis of PRDM action mechanism appears very important. Data obtained by RT-PCR and Western blot analysis in C2C12 cell line showed that the expression of PRDM2 gene was selectively modulated during differentiation, because of the differentiated cells showed reduced levels of expression of RIZ1 than myoblasts. This trend is in disagreement with the experimental evidence obtained in epithelial cell line models [78] and lymphocytes [94] in which treatment with differentiating agents, or

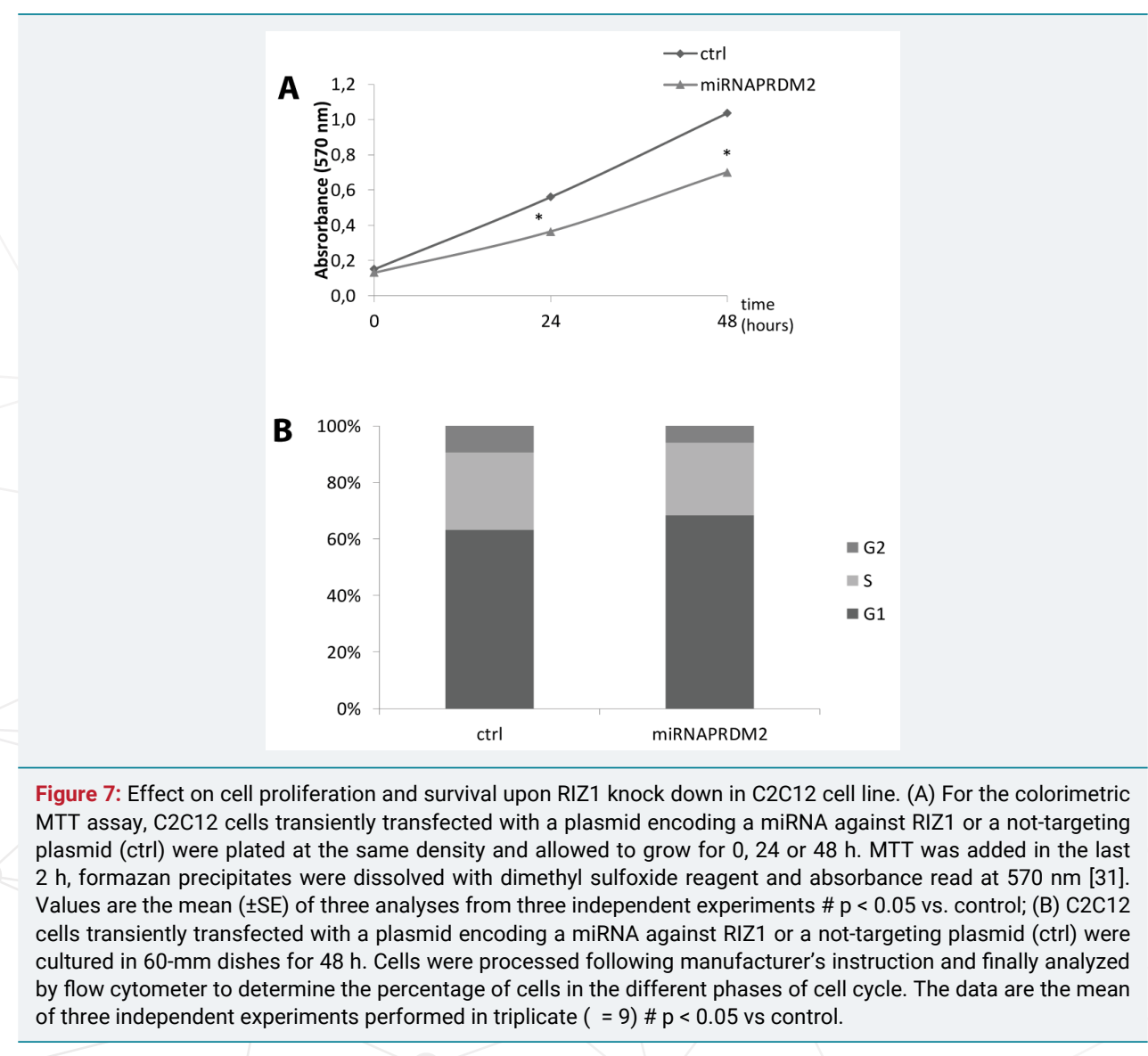


the stimulation of cell proliferation, respectively, caused the increase and decreased of PRDM2/RIZ1 expression. On the contrary, there are some similarities with the experimental evidence obtained with the osteosarcoma cell line (SAOS2), in which PRDM2/RIZ1 showed an elevated expression in proliferating cells, compared to cells that had temporarily left the cell cycle [95]. These suggestions left us to speculate that RIZ can be related to the cell type and in the mesenchymal cells perhaps cell cycle escape and subsequent differentiation coincide with RIZ1 expression level reduction: immunocytochemistry experiments, performed in myoblasts and myotubes, showed that during differentiation there is an intracellular redistribution of RIZ protein, predominantly localized in the perinuclear and nuclear area. This phenomenon, as myeloid leukemia cell line HL60, could be interpreted as an intranuclear confinement of RIZ protein. Expression level analysis by qRT-PCR of other member of PRDM family gene PRDM4 and PRDM10 showed that the differentiation induction was characterized by a reduction of its expression levels. In order to confirm the involvement of PRDM2 gene in the proliferation-differentiation switch, we performed knockdown experiments. Interestingly, the PRDM2 gene silencing was characterized by a Myogenin expression level increasing, suggesting its peculiar role in the transcriptional control of myogenin expression. ChIP experiments performed with MyoD and RIZ antibodies on E2/E1 Myogenin promoter region in proliferation condition and after $24 \mathrm{~h}$ from differentation induction, confirmed a binding on the Myogenin promoter. As demonstrated by Mal A. [93], Lys-9 of H3 histones were methylated by SUV39H1 [96], surrounding the myogenin promoter in undifferentiated myoblasts. This marking was dramatically reduced in myoblasts that had undergone differentiation. We hypothesize that another member of SET family protein, RIZ1, can modulate myogenin expression, and RIZ1 interference reduced the expression level of PRDM4 and PRDM10 genes, lead us to speculate that the members of the family have a redundant PRDM behavior and/or cooperate in the transition proliferation-differentiation. Futhermore PRDM2 silencing induced a G1 phase delay and a reduction of proliferation.

\section{Conclusion}

In conclusion, our studies suggest that PRDM2, PRDM4 and PRDM10 play a pivotal role in the proliferation-differentiation switch of myoblast in myotubes.

\section{Acknowledgements}

This work was supported by grants from the Italian Ministry of University and Scientific Research PRIN.

\section{References}

1. Singh K, Dilworth FJ. Differential modulation of cell cycle progression distinguishes members of the myogenic regulatory factor family of transcription factors. FEBS J. 2013; 280: 3991-4003. Ref.: https://goo.gl/mw5Y9p

2. Davis RL, Weintraub H. Acquisition of myogenic specificity by replacement of three amino acid residues from MyoD into E12. Science. 1992; 256: 1027-1030. Ref.: https://goo.gl/kD7f3S

3. Tapscott SJ, Davis RL, Thayer MJ, Cheng PF, Weintraub H, et al. MyoD1: a nuclear phosphoprotein requiring a Myc homology region to convert fibroblasts to myoblasts. Science. 1988; 242: 405-11. Ref.: https://goo.gl/6eXUeW

4. Atchley WR, Fitch WM, Bronner-Fraser M. Molecular evolution of the MyoD family of transcription factors. Proc Natl Acad Sci.1994; 91: 11522-11526. Ref.: https://goo.gl/d2oZHf

5. Berkes, CA, Tapscott SJ. MyoD and the transcriptional control of myogenesis. Semin Cell Dev Biol. 2005; 16: 585-595. Ref.: https://goo.gl/cSHJLx

6. Braun T, Buschhausen-Denker G, Bober E, Tannich E, Arnold HH. A novel human muscle factor related to but distinct from MyoD1 induces myogenic conversion in 10T1/2 fibroblasts. EMBO J. 1989; 8: 701-709. Ref.: https://goo.gl/Vwy7uo 
7. Kablar B, Rudnicki MA. Development in the absence of skeletal muscle results in the sequential ablation of motor neurons from the spinal cord to the brain. Dev Biol. 1999; 208: 93-109. Ref.: https://goo.gl/z5nXSY

8. Rudnicki, MA, Schnegelsberg PN, Stead RH, Braun T, Arnold HH., et al. MyoD or Myf-5 is required for the formation of skeletal muscle. Cell 1993; 75: 1351-1359. Ref.: https://goo.gl/cWenqL

9. Tajbakhsh S, Rocancourt D, Buckingham M. Muscle progenitor cells failing to respond to positional cues adopt non-myogenic fates in myf-5 null mice. Nature. 1996; 384: 266-270. Ref.: https://goo.gl/FpK37B

10. Reijntjes $S$, Francis-West $P$, Mankoo BS. Retinoic acid is both necessary for and inhibits myogenic commitment and differentiation in the chick limb. Int $\mathrm{J}$ Dev Biol. 2010; 54: 125-134. Ref.: https://goo.gl/pD5Xh2

11. Ustanina S, Carvajal J, Rigby P, Braun T. The myogenic factor Myf5 supports efficient skeletal muscle regeneration by enabling transient myoblast amplification. Stem Cells. 2007; 25: 2006-2016. Ref.: https://goo.gl/qJ7YU6

12. Gayraud-Morel B, Chrétien F, Flamant $P$, Gomès $D$, Zammit PS, Tajbakhsh $S$. A role for the myogenic determination gene Myf5 in adult regenerative myogenesis. Dev Biol. 2007; 312: 13-28. Ref.: https://goo.gl/DR6jKq

13. Montarras $D$, Lindon $C$, Pinset $C$, Domeyne $P$. Cultured myf5 null and myoD null muscle precursor cells display distinct growth defects. Biol cell. 2000; 92: 565-572. Ref.: https://goo.gl/rQLzi9

14. Panda AC, Abdelmohsen K, Martindale JL, Di Germanio C, Yang X, et al. Novel RNA-binding activity of MYF5 enhances Ccnd1/Cyclin D1 mRNA translation during myogenesis. Nucleic Acids Res. 2016; 44: 2393-2408. Ref.: https://goo.gl/oKMM6P

15. Wright WE, Sassoon DA, Lin VK. Myogenin, a factor regulating myogenesis, has a domain homologous to MyoD. Cell. 1989; 56: 607-617. Ref.: https://goo.gl/DmD2qg

16. Hashimoto $N$, Ogashiwa $M$, Iwashita $S$. Role of tyrosine kinase in the regulation of myogenin expression. Eur J Biochem 1995; 227: 379-387. Ref: https://goo.gl/Lz6TQF

17. Rhodes SJ, Konieczny SF. Identification of MRF4: a new member of the muscle regulatory factor gene family. Genes Dev. 1989; 3: 2050-2061. Ref: https://goo.gl/uMgCbh

18. Arnold HH, Braun T. Targeted inactivation of myogenic factor genes reveals their role during mouse myogenesis: a review. Int J Dev Biol. 1996; 40: 345-353. Ref: https://goo.gl/WJ5MPb

19. Moncaut N, Rigby PWJ, Carvajal, JJ. Dial M (RF) for myogenesis. FEBS J. 2013; 280: 3980-3990. Ref: https://goo.gl/YSZk62

20. Chandra S, Terragni J, Zhang G, Pradhan S, Haushka S, et al. Tissue-specific epigenetics in gene neighborhoods: myogenic transcription factor genes. Hum Mol Genet. 2015; 24: 4660-4673. Ref: https://goo.gl/4SPWMT

21. Molkentin JD, Black BL, Martin JF, Olson EN. Cooperative activation of muscle gene expression by MEF2 and myogenic bHLH proteins. Cell. 1995; 83: 1125-1136. Ref: https://goo.gl/YLEyhp

22. Pon JR, Marra MA. MEF2 transcription factors: developmental regulators and emerging cancer genes. Oncotarget. 2016; 7: 22970-22312. Ref: https://goo.gl/kbzRUj

23. Cao Y, Yao Z, Sarkar D, Lawrence M, Sanchez GJ, et al. Genome-wide MyoD binding in skeletal muscle cells: a potential for broad cellular reprogramming. Dev Cell 2010; 18: 662-674. Ref: https://goo.gl/M39LeS

24. Soleimani VD, Yin H, Jahani-Asl A, Ming H, Kockx CEM, et al. Snail regulates MyoD binding-site occupancy to direct enhancer switching and differentiation-specific transcription in myogenesis. Mol Cell. 2012; 47: 457-468. Ref: https://goo.gl/HTLeyZ

25. Murre $\mathrm{C}$, McCaw PS, Vaessin H, Caudy M, Jan LY, et al. Interactions between heterologous helixloophelix proteins generate complexes that bind specifically to a common DNA sequence. Cell 1989; 58: 537-544. Ref: https://goo.gl/vcQBSt

26. Blackwell TK, Weintraub H. Differences and similarities in DNA-binding preferences of MyoD and E2A protein complexes revealed by binding site selection. Science. 1990; 250: 1104-1110. Ref: https://goo.gl/MEyBj2

27. Blais $A$, Tsikitis $M$, Acosta-Alvear $D$, Sharan $R$, Kluger $Y$, et al. An initial blueprint for myogenic differentiation. Genes Dev. 2005; 19: 553-569. Ref: https://goo.gl/FPp6dQ 
28. Aziz A, Liu QC, Dilworth FJ. Regulating a master regulator: establishing tissuespecific gene expression in skeletal muscle. Epigenetics 2010; 5: 691-695. Ref: https://goo.gl/j6xEnj

29. De Falco G, Comes F, Simone C. pRb: master of differentiation. Coupling irreversible cell cycle withdrawal with induction of muscle-specific transcription. Oncogene. 2006; 25: 5244-5249. Ref: https://goo.gl/ZPQ9W8

30. Giacinti C, Bagella L, Puri PL, Giordano A, Simone C. MyoD recruits the cdk9/cyclin T2 complex on myogenic-genes regulatory regions. J Cell Physiol. 2006; 206: 807-813. Ref: https://goo.gl/mCAE7b

31. Martelli F, Cenciarelli C, Santarelli G, Polikar B, Felsani A, et al. MyoD induces retinoblastoma gene expression during myogenic differentiation. Oncogene. 1994; 9: 3579-3590. Ref: https://goo.gl/LVfg3U

32. Halevy O, Novitch BG, Spicer DB, Skapek SX, Rhee J, et al. Correlation of terminal cell cycle arrest of skeletal muscle with induction of p21 by MyoD. Science. 1995; 267: 1018-1021. Ref: https://goo.gl/aXwh2j

33. Basile V, Baruffaldi F, Dolfini D, Belluti S, Benatti $P$, et al. NF-YA splice variants have different roles on muscle differentiation. Biochim. Biophys Acta 2016; 1859: 627-638. Ref: https://goo.gl/RXTp41

34. Besson A, Dowdy SF, Roberts JM. CDK Inhibitors: Cell Cycle Regulators and Beyond. Dev Cell 2008; 14: 159-169. Ref: https://goo.gl/LYEJ4R

35. Zhang $\mathrm{P}$, Wong $\mathrm{C}$, Liu D, Finegold M, Harper JW, et al. p21(CIP1) and p57(KIP2) control muscle differentiation at the myogenin step. Genes Dev. 1999; 13: 213-224. Ref: https://goo.gl/V2osBr

36. Fumasoni I, Meani N, Rambaldi D, Scafetta G, Alcalay M, et al. Family expansion and gene rearrangements contributed to the functional specialization of PRDM genes in vertebrates. BMC Evol Biol. 2007; 7: 187. Ref: https://goo.gl/w36vh7

37. Vervoort M, Meulemeester D, Béhague J, Kerner P. Evolution of Prdm Genes in Animals: Insights from Comparative Genomics. Mol Biol Evol. 2016; 33: 679-696. Ref: https://goo.gl/hQNY1L

38. Kinameri E, Inoue T, Aruga J, Imayoshi I, Kageyama R, et al. Prdm proto-oncogene transcription factor family expression and interaction with the Notch-Hes pathway in mouse neurogenesis. PLoS One. 2008; 3: e3859. Ref: https://goo.gl/26UZEg

39. Huang S. Histone methyltransferases, diet nutrients and tumour suppressors. Nat Rev

40. Cancer. 2002; 2: 469-476. Ref: https://goo.gl/b73pB9

41. Fog CK, Galli GG, Lund AH. PRDM proteins: important players in differentiation and disease. Bioessays. 2012; 34: 50-60. Ref: https://goo.gl/G8bjFM

42. Gyory I, Wu J, Fejér G, Seto E, Wright KL. PRDI-BF1 recruits the histone H3 methyltransferase G9a in transcriptional silencing. Nat Immunol. 2004; 5: 299-308. Ref: https://goo.gl/z2qBqf

43. Duan Z, Person RE, Lee HH, Huang S, Donadieu J, et al. Epigenetic regulation of protein-coding and microRNA genes by the Gfi1-interacting tumor suppressor PRDM5. Mol Cell Biol. 2007; 27: 68896902. Ref: https://goo.gl/o9rsFs

44. Davis CA, Haberland M, Arnold MA, Sutherland LB, McDonald OG, et al. PRISM/PRDM6, a transcriptional repressor that promotes the proliferative gene program in smooth muscle cells. Mol Cell Biol. 2006; 26: 2626-2636. Ref: https://goo.gl/F2qSto

45. Zhang Y, Stehling-Sun S, Lezon-Geyda K, Juneja SC, Coillard L, et al. PR-domain-containing Mds1Evi1 is critical for long-term hematopoietic stem cell function. Blood 2011; 118: 3853-3861. Ref: https://goo.gl/CAgCMP

46. Derunes C, Briknarová K, Geng L, Li S, Gessner CR, et al. Characterization of the PR domain of RIZ1 histone methyltransferase. Biochem Biophys Res Commun. 2005: 333: 925-934. Ref: https://goo.gl/6EFkQu

47. Eom GH, Kim K, Kim SM, Kee H J, Kim JY, at al.. Histone methyltransferase PRDM8 regulates mouse testis steroidogenesis. Biochem Biophys Res Commun 2009; 388: 131-136. Ref: https://goo.gl/F8KSX8

48. Hayashi K, Yoshida K, Matsui YA. Histone H3 methyltransferase controls epigenetic events required for meiotic prophase. Nature. 2005; 438: 374-378. Ref: https://goo.gl/eFVaU5

49. Fears S, Mathieu C, Zeleznik-Le N, Huang S, Rowley JD, et al. Intergenic splicing of MDS1 and EVI1 occurs in normal tissues as well as in myeloid leukemia and produces a new member of the PR domain family. Proc Natl Acad Sci USA. 1996; 93: 1642-1647. Ref: https://goo.gl/M8fJtd 
50. Sun X.J, Xu PF, Zhou T, Hu M, Fu CT, et al. Genome-wide survey and developmental expression mapping of zebrafish SET domain-containing genes. PLoS One. 2008; 3: e1499. Ref: https://goo.gl/gcTckQ

51. Wu H, Min J, Lunin VV, Antoshenko T, Dombrovski L, et al. Structural Biology of Human H3K9 Methyltransferases. PLoS One. 2010; 5: e8570. Ref: https://goo.gl/Vy9nKX

52. Zannino DA, Sagerström CG. An emerging role for prdm family genes in dorsoventral patterning of the vertebrate nervous system. Neural Dev. 2015; 10: 24. Ref: https://goo.gl/u2LDuH

53. Rea S, Eisenhaber F, Carroll D, Strahl BD, Sun ZW, et al. Regulation of chromatin structure by sitespecific histone H3 methyltransferases. Nature. 2000; 406: 593-599. Ref: https://goo.gl/Pck8uA

54. Hohenauer T, Moore AW. The Prdm family: expanding roles in stem cells and development. Development. 2012; 139: 2267-2282. Ref: https://goo.gl/jPCxk1

55. Györy I, Fejér G, Ghosh N, Seto E, Wright KL. Identification of a functionally impaired positive regulatory domain I binding factor 1 transcription repressor in myeloma cell lines J Immunol. 2003; 170: 3125-3133. Ref: https://goo.gl/rQW9ti

56. Hirai H. The transcription factor Evi-1. Int J Biochem Cell Biol. 1999; 31: 1367-1371. Ref: https://goo. gl/3TKze6

57. Liu L, Shao G, Steele-Perkins G, Huang S. The retinoblastoma interacting zinc finger gene RIZ produces a PR domain-lacking product through an internal promoter. J Biol Chem. 1997; 272: 29842991. Ref: https://goo.gl/A3RY5D

58. Zazzo E, De Rosa C, Abbondanza C, Moncharmont. B PRDM Proteins: Molecular Mechanisms in Signal Transduction and Transcriptional Regulation. Biology (Basel). 2013; 2: 107-141. Ref: https:// goo.gl/GA4nXP

59. Zazzo E, Porcile C, Bartollino S, Moncharmont B. Critical Function of PRDM2 in the Neoplastic Growth of Testicular Germ Cell Tumors. Biology (Basel). 2016; 5: 54. Ref: https://goo.gl/NAKVav

60. Geli J, Kiss N, Kogner P, Larsson C. Suppression of RIZ in biologically unfavourable neuroblastomas. Int J Oncol. 2010; 37: 1323-1330. Ref: https://goo.gl/CGkbaM

61. Geli J, Nord B, Frisk T, Edström Elder E, Ekström TJ, et al. Deletions and altered expression of the RIZ1 tumour suppressor gene in $1 \mathrm{p} 36$ in pheochromocytomas and abdominal paragangliomas. Int $J$ Oncol. 2005; 26: 1385-1391. Ref: https://goo.gl/GCX4Yd

62. Piao Z, Fang W, Malkhosyan S, Kim H, Horii A, et al. Frequent frameshift mutations of RIZ in sporadic gastrointestinal and endometrial carcinomas with microsatellite instability. Cancer Res. 2000; 60: 4701-4704. Ref: https://goo.gl/W7x2i6

63. Poetsch M, Dittberner T, Woenckhaus C. Frameshift mutations of RIZ, but no point mutations in RIZ1 exons in malignant melanomas with deletions in 1p36. Oncogene. 2002; 21: 3038-3042. Ref: https:// goo.gl/aeV6mN

64. Sakurada K, Furukawa T, Kato Y, Kayama, T, Huang, S. et al. RIZ, the retinoblastoma protein interacting zinc finger gene, is mutated in genetically unstable cancers of the pancreas, stomach, and colorectum. Genes Chromosomes Cancer. 2001; 30: 207-211. Ref: https://goo.gl/RPyP9V

65. Sasaki O, Meguro K, Tohmiya Y, Funato T, Shibahara, S, et al. Altered expression of retinoblastoma protein-interacting zinc finger gene, RIZ, in human leukaemia. Br J Haematol. 2002; 119: 940-948. Ref: https://goo.gl/7BPA7K

66. Steele-Perkins G, Fang W, Yang XH, Van Gele M, Carling T, et al. Tumor formation and inactivation of $\mathrm{RIZ1}$, an Rb-binding member of a nuclear protein-methyltransferase superfamily. Genes Dev. 2001; 15: 2250-2262. Ref: https://goo.gl/LDUqkS

67. Mzoughi S, Tan YX, Low D, Guccione E. The role of PRDMs in cancer: one family, two sides. Curr Opin Genet Dev. 2016; 36: 83-91. Ref: https://goo.gl/aLyPC2

68. Marmorstein R. Structure of SET domain proteins: a new twist on histone methylation.

69. Trends Biochem Sci. 2003; 28: 59-62. Ref: https://goo.gl/fC7vwY

70. Kim KC, Geng L, Huang S. Inactivation of a histone methyltransferase by mutations in human cancers. Cancer Res. 2003; 63: 7619-7623. Ref: https://goo.gl/aTL3SA

71. Matsuo H, Goyama S, Kamikubo Y, Adachi S. The subtype-specific features of EVI1 and PRDM16 in acute myeloid leukemia. Haematologica. 2015; 100: e116-e117. Ref: https://goo.gl/X2BvyD 
72. Seale P, Bjork B, Yang W, Kajimura S, Chin S, et al. PRDM16 controls a brown fat/skeletal muscle switch. Nature. 2008; 454: 961-967. Ref: https://goo.gl/emNeao

73. Yin H, Pasut A, Soleimani VD, Bentzinger CF, Antoun G, et al. MicroRNA-133 Controls Brown Adipose Determination in Skeletal Muscle Satellite Cells by Targeting Prdm16. Cell Metab. 2013; 17: $210-224$. Ref: https://goo.gl/xU9ohE

74. Deng Q, Huang S. PRDM5 is silenced in human cancers and has growth suppressive activities. Oncogene. 2004; 23: 4903-4910. Ref: https://goo.gl/fxFuV8

75. Watanabe $\mathrm{Y}$, Toyota $\mathrm{M}$, Kondo $\mathrm{Y}$, Suzuki $\mathrm{H}$, Imai $\mathrm{T}$, et al. PRDM5 identified as a target of epigenetic silencing in colorectal and gastric cancer. Clin Cancer Res. 2007; 13: 4786-4794. Ref: https://goo.gl/heTiF3

76. Cheng HY, Chen XW, Cheng L, Liu YD, Lou G. DNA methylation and carcinogenesis of PRDM5 in cervical cancer. J Cancer Res Clin Oncol. 2010; 136: 1821-1825. Ref: https://goo.gl/uJwpLx

77. Huang S. The retinoblastoma protein-interacting zinc finger gene RIZ in 1p36-linked cancers. Front Biosci. 1999; 4: D528-32. Ref: https://goo.gl/MEhmBJ

78. Jiang GI, Liu L, Buyse IM, Simon D, Huang S. Decreased RIZ1 expression but not RIZ2 in hepatoma and suppression of hepatoma tumorigenicity by RIZ1. Int J cancer 1999; 83: 541-546. Ref: https://goo.gl/6tBdTJ

79. Dong SW, Zhang YW, Chen Y, Wang S, Sun P, et al. PRDIBF1-RIZ domain of retinoblastoma proteininteracting zinc finger gene 1 induces apoptosis and exerts anticancer activity in esophageal squamous cell carcinoma cells. Oncol Lett. 2015; 9: 341-346. Ref: https://goo.gl/Uv8Xc1

80. Gazzerro P, Abbondanza C, Arcangelo A, Rossi M, Medici N, et al. Modulation of RIZ gene expression is associated to estradiol control of MCF-7 breast cancer cell proliferation. Exp Cell Res. 2006; 312: 340-9. Ref: https://goo.gl/GzBzCz

81. Rossi M, Abbondanza C, Arcangelo A, Gazzerro $\backslash$, Medici N, Moncharmont B, Puca GA. The Znfinger domain of RIZ protein promotes MCF-7 cell proliferation. Cancer Lett. 2004; 215: 229-37. Ref: https://goo.gl/Sj7TsU

82. Medici N, Abbondanza C, Nigro V, Rossi V, Piluso G, et al. Identification of a DNA binding protein cooperating with estrogen receptor as RIZ (retinoblastoma interacting zinc finger protein). Biochem Biophys Res Commun. 1999; 264: 983-989. Ref: https://goo.gl/uN4qs9

83. Abbondanza C, Medici N, Nigro V, Rossi V, Gallo L, et al. The retinoblastoma-interacting zinc-finger protein RIZ is a downstream effector of estrogen action. Proc Natl Acad Sci. USA. 2000; 97: 31303135. Ref: https://goo.gl/XoLXWf

84. He L, Yu JX, Liu L, Buyse IM, Wang MS, et al. RIZ1, but not the alternative RIZ2 product of the same gene, is underexpressed in breast cancer, and forced RIZ1 expression causes G2-M cell cycle arrest and/or apoptosis. Cancer Res. 1998; 58: 4238-4244. Ref: https://goo.gl/6xk6VN

85. Koh-Stenta X, Joy J, Poulsen A, Li R, Tan Y, et al. Characterization of the histone methyltransferase PRDM9 using biochemical, biophysical and chemical biology techniques. Biochem J 2014; 461: 323334. Ref: https://goo.gl/M3WQge

86. Li X, Wang J, Jiang Z, Guo F, Soloway PD, Zhao R. Role of PRDM16 and its PR domain in the epigenetic regulation of myogenic and adipogenic genes during transdifferentiation of C2C12 cells. Gene 2015; 570: 191-198. Ref: https://goo.gl/ixp4Kr

87. Harms MJ, Ishibashi J, Wang W, Lim HW, Goyama S, et al. Prdm16 is Required for the Maintenance of Brown Adipocyte Identity and Function in Adult Mice. Cell Metab. 2014; 19: 593-604. Ref: https://goo.gl/yTqTsM

88. Burattini S, Ferri $\mathrm{P}$, Battistelli M, Curci R, Luchetti $\mathrm{F}$, et al. C2C12 murine myoblasts as a model of skeletal muscle development: morpho-functional characterization. Eur J Histochem. 2004; 48: 223 233. Ref: https://goo.gl/MwDgzE

89. Cheedipudi S, Puri D, Saleh A, Gala HP, Rumman M, et al. A fine balance: epigenetic control of cellular quiescence by the tumor suppressor PRDM2/RIZ at a bivalent domain in the cyclin a gene. Nucleic Acids Res. 2015; 43: 6236-56. Ref: https://goo.gl/B3UYF7

90. Sabourin LA, Rudnicki M.A. The molecular regulation of myogenesis. Clin Genet. 2000; 57: 16-25. Ref: https://goo.gl/yHVw8p

91. Morano A, Angrisano T, Russo G, Landi R, Pezone A, et al. Targeted DNA methylation by homologydirected repair in mammalian cells. Transcription reshapes methylation on the repaired gene. Nucleic Acids Res. 2014; 42: 804-821. Ref: https://goo.gl/NUDMA3 
92. Pfaffl MW. A new mathematical model for relative quantification in real-time RT-PCR. Nucleic Acids Res. 2001; 29: 45. Ref: https://goo.gl/ABUUGz

93. Laemmli UK. Cleavage of structural proteins during the assembly of the head of bacteriophage T4. Nature. 1970; 227: 680-685. Ref: https://goo.gl/jS8Gfa

94. Crescenzi M, Crouch DH, Tatò F. Transformation by myc prevents fusion but not biochemical differentiation of $\mathrm{C} 2 \mathrm{C} 12$ myoblasts: mechanisms of phenotypic correction in mixed culture with normal cells. J Cell Biol. 1994; 125: 1137-1145. Ref: https://goo.gl/bNkD5j

95. Mal A, Harter ML. MyoD is functionally linked to the silencing of a muscle-specific regulatory gene prior to skeletal myogenesis. Proc Natl. Acad Sci. 2003; 100: 1735-1739. Ref: https://goo.gl/cdc72F

96. Gazzerro P, Bontempo P, Schiavone EM, Abbondanza C, Moncharmont B, et al. Differentiation of myeloid cell lines correlates with a selective expression of RIZ protein. Mol Med. 2001; 7: 552-560. Ref: https://goo.gl/PJDGtc

97. Abbondanza C, Nigris F, Rosa C, Rossiello R, Puca GA, et al. Silencing of YY1 downregulates RIZ1 promoter in human osteosarcoma. Oncol Res. 2008; 17: 33-41. Ref: https://goo.gl/Cuwz43

98. Mal AK. Histone methyltransferase Suv39h1 represses MyoD-stimulated myogenic differentiation. EMBO J. 2006; 25: 3323-3334. Ref: https://goo.gl/jr1Sse 